\title{
Effects of yam dioscorin interventions on improvements of the metabolic syndrome in high-fat diet-induced obese rats
}

\author{
Shen-Liang Shih ${ }^{1 \dagger}$, Yin-Shiou Lin ${ }^{2 \dagger}$, Shyr-Yi Lin ${ }^{3,4^{*}}$ and Wen-Chi Hou ${ }^{2,5,6^{*}}$
}

\begin{abstract}
Background: The metabolic syndrome (MS) is termed a cluster of multiple metabolic risk criteria which is positively correlated with cardiovascular disease and type 2 diabetes mellitus (DM). Yam dioscorins have been reported to exhibit biological activities, however, little is known their preventive effects on the MS. Therefore, a high-fat (HF) diet was used to induce Wistar rat obesity and then yam dioscorin $(50 \mathrm{mg} / \mathrm{kg}$, dio50) was intervened daily concurrent HF diet (HF diet + dio50) for five weeks to check the changes of weights of body and tissues, blood pressures, and impaired glucose tolerances. The in vitro peptic hydrolysates of dioscorin with molecular mass between $3 \mathrm{kDa}$ and $10 \mathrm{kDa}$ and less than $3 \mathrm{kDa}$ were used to determine dipeptidyl peptidase IV (DPP IV) inhibitory activities which DPP IV inhibitor has been reported to prevent and treat type $2 \mathrm{DM}$.

Results: There were no significant difference in body weights, feed intakes, feed conversion, and weights of adipose tissues of obese rats in groups of HF and (HF diet + dio50). However, the systolic blood pressures in obese rats of 2-, 3and 4-week dioscorin interventions were showed significantly lower $(P<0.05)$ compared to the HF group. The dioscorin intervention ( $\mathrm{HF}+$ dio50) was showed significantly different $(P<0.05)$ and improved the impaired glucose tolerances compared to HF group in obese rats by the oral glucose tolerance tests. It was also found that the fraction with different molecular mass of dioscorin peptic hydrolysates $(5 \mathrm{mg} / \mathrm{ml})$ showed inhibitory activities against DPP IV using sitagliptin phosphate as positive controls.
\end{abstract}

Conclusions: Yam dioscorins exhibit improved MS activities in obese rats which the related mechanisms may need further investigations.

Keywords: Dioscorin; Dipeptidyl peptidase IV (DPP IV); Metabolic syndrome (MS); Peptic hydrolysates; Systolic blood pressure; Yam

\section{Background}

The metabolic syndrome (MS) is termed a cluster of five multiple metabolic risk criteria, including (1) abdominal obesity (central obesity), (2) hypertriglyceridemia [fasting triglycerides (TGs) $\geq 150 \mathrm{mg} / \mathrm{dl}$ ], (3) low serum high-density lipoprotein cholesterol (HDL $\leq$ $40 \mathrm{mg} / \mathrm{dl}$ ), (4) elevated blood pressure (systolic $\geq$ $130 \mathrm{mmHg}$ or diastolic $\geq 85 \mathrm{mmHg}$ ), and (5) high fasting

\footnotetext{
* Correspondence: sylin@tmu.edu.tw; wchou@tmu.edu.tw

${ }^{\dagger}$ Equal contributors

${ }^{3}$ Department of Primary Care Medicine, Taipei Medical University Hospital,

Taipei, Taiwan

${ }^{2}$ Graduate Institute of Pharmacognosy, Taipei Medical University, Taipei, Taiwan

Full list of author information is available at the end of the article
}

blood glucose $(\geq 110 \mathrm{mg} / \mathrm{dl})$, and an increasing obesity and sedentary lifestyles relate positively the rising MS worldwide prevalence (Day 2007; Alberti et al. 2009). A general diagnosis with three out of above-mentioned five criteria can recognize as the MS (Day 2007). Insulin resistance and impaired glucose tolerance are also two important metabolic risk criteria which may involve in factors for the MS general diagnosis (Day 2007). The health risks of MS associated with obesity vary among individuals, but consistently include type 2 diabetes mellitus (type $2 \mathrm{DM}$ ), hypertension, coronary heart disease and cancer (Zimmet 1982; Prentice 2006). The abdominal obesity may play the central role in MS which is the situation of exceeding visceral fat deposited in peritoneal cavity, and will initiate inflammation and dyslipidemia, increase the blood pressure 
and decrease insulin sensitivity accompanied with abnormal blood glucose. Obesity is blamed as a major contributing factor in over 0.3 million deaths per year in the America and related economic costs over US 100 billion per year (Daniels 2006; Rodgers et al. 2012). In fact, obesity associated with diabetes are considered not only a clinical problem but also a public health issue in many countries, and $80 \%$ of overweight people are also diagnosed with type $2 \mathrm{DM}$ which are referred as "the twin epidemics" (Smyth and Heron 2005).

Several animal models are established and suitable for one or more metabolic risk criteria in MS studies (Panchal and Brown 2011), such as genetic rodent models, including $d b / d b$ mice, $o b / o b$ mice, Zucker diabetic fatty rats, and Otsuka Long-Evans Tokushima fatty (OLETF) rats etc., however, such genetic mutations in established rodent animals are few reported in humans; on the other hand, the diet-induced rodent models may mimic closely to MS symptoms in humans, including fructose-induced, sucroseinduced, and high-fat (HF) diet induced rodent animals (Panchal and Brown 2011). The HF diets are reported to induce overweight, obesity, dyslipidemia, insulin resistance, and high blood pressures in rodent animals (Agulia and Mandarim-de-Lacerda 2003; Woods et al. 2003; Kobayasi et al. 2010), and are widely used for MS study (Frigolet et al. 2013).

The dipeptidyl peptidase IV (DPP IV) is a serine-type proteinase (EC 3.4.14.5) which metabolizes peptide hormones, such as glucagon-like peptide-1 (GLP-1), an insulinotropic peptide hormone can stimulate glucosedependent insulin secretions (Mentlein 2005; Drucker 2006; Idris and Donnelly 2007). DPP IV inhibitors that control the glycermia by modulating the GLP-1 levels are currently developed for type 2 DM treatments (Smyth and Heron 2005; Idris and Donnelly 2007). DPP IV cleaves the Pro or Ala at the second position of the active $N$-terminal GLP-1(7-37) or GLP-1(7-36) amide which results in functional inactive GLP-1(9-37) or GLP-1(9-36) amide (Drucker 2006; Idris and Donnelly 2007). Therefore, researchers attempted to isolate potential DPP IV inhibitory peptides from protein hydrolysates, such as pepsin-pancreatin hydrolysates of sodium caseinate, skim milk powders and milk protein concentrates (Lacroix and Li-Chan 2012), Umamizyme G hydrolysates of defatted rice bran (Hatanaka et al. 2012), and pepsin-treated whey protein (Lacroix and Li-Chan 2013).

Yams are recognized as herbal plants since the tuber dried slices are widely used as Chinese herbal medicines, and the fresh tuber has also been a staple food in West Africa, Southern Asia, and the Caribbean. The tubers of yam storage protein, dioscorin, account for about $90 \%$ of the extractable water-soluble proteins from different species as estimated by the immune staining method (Hou et al. 2000). The yam dioscorin and/or its peptic hydrolysates have been reviewed for biological activities in vitro and/or in vivo (Lu et al. 2012), among which the antihypertensive activities (Hsu et al. 2002; Lin et al. 2006; Liu et al. 2009a,b; Lin et al. 2014) and antioxidant activities (Hou et al. 2001; Liu et al. 2006; Han et al. 2013, 2014a,b,c) may involve in MS studies. Therefore, a HF diet which the fat composition provide $60 \%$ of total calories is used to induce obese rats and then yam dioscorin is intervened to observe the changes of body weights, blood pressures, and glucose tolerances. It is also to test the pepsin hydrolysates of yam dioscorin to evaluate DPP IV inhibitory activities.

\section{Methods \\ Materials}

DPP IV (lyophilized powder, $\geq 10$ units/mg protein, D7052), glucose, Gly-Pro $p$-nitroanilide, pepsin (3460 units/ mg solid, P-6887), and sitagliptin phosphate were purchased from Sigma Chemical Co. (St. Louis, MO). The HF diet for obesity induction (fat composition provide 60\% of total calories, D12942) was purchased from Research Diets, Inc. (NJ, USA). The standard mouse/rat chow (fat composition provide $12.137 \%$ of total calories, Prolab ${ }^{\bullet} \mathrm{RH} 2500$, 5P14 Diet; PMI Nutrition International, MO, USA).

\section{HF diets-induced obese rats for MS studies}

Male 10-week-old Wistar rats $(\mathrm{N}=24)$ were purchased from National Laboratory Animal Center (Taipei, Taiwan) and housed in wire-bottomed stainless steel cages in a temperature- and humidity-controlled room $\left(\right.$ at $22^{\circ} \mathrm{C}$ ) with a 12-h light/dark cycle which had free access to the feeds and water. All animal experimental procedures were reviewed and approved by the Institutional Animal Care and Use Committee, Taipei Medical University (LAC-1000038). After acclimation for one week, rats were randomly divided into three groups ( $\mathrm{N}=8$ for each group), including a blank group for standard mouse/rat chow and two HF diet-induced obese groups (one control as HF group and one dioscorin-intervened group) for 70-days. In the dioscorin intervened group, yam dioscorin $(50 \mathrm{mg} / \mathrm{kg}$, dio50) was intervened daily concurrent $\mathrm{HF}$ diets ( $\mathrm{HF}+$ dio50) from day-36 to day-70. The rat weights and feed intakes were recorded during experiments. The feed conversion is defined as a ratio of amounts of feed intakes ( $\mathrm{g}$ ) divided by rat weight gains (g) during experimental periods. Rats were sacrificed, organs (heart, lung, liver, kidney, and spleen) and adipose tissues (retroperitoneal fat, mesenteric fat, visceral fat, and testicle fat) were collected and weighted for comparisons.

\section{Changes of blood pressures in the dioscorin intervention of HF diet-induced obese rats}

The systolic blood pressure (SBP) and diastolic blood pressure (DBP) of rats were measured at the end of each 
week after dioscorin intervention for 1-, 2-, 3-, and 4weeks by using an indirect tail-cuff blood pressure meter (BP-98A, Softron Co. Ltd. Tokyo, Japan). Distilled water $(0.5 \mathrm{ml})$ was administered to the rats in the normal diet group (the blank) and HF group (the control) instead of dioscorin solutions for comparisons.

\section{Impaired glucose tolerances in the dioscorin interventions of HF diet-induced obese rats by oral glucose tolerance tests}

Impaired glucose tolerance of HF diet-induced obese rats were measured by oral glucose tolerance tests (OGTT) following the previous report (Ito et al. 2001; Andrikopoulos et al. 2008) with modifications. Rats of each group at the ends of the $10^{\text {th }}$-week were fasted for 16 hours and glucose was administered by oral gavage at $1 \mathrm{~g} / \mathrm{kg}$ body weight. Blood $(0.1 \mathrm{ml})$ was obtained from the tail vein of rats at $0,5,30,60,90$, and 120 min after the glucose loads. Plasma glucose were determined by using RANDOX glucose kit (Randox Laboratories-US, Ltd. USA). The assay principle is based on the hydrogen peroxide generation catalyzed by glucose oxidase and further reacted with phenol and 4-aminophenazone to produce reddish violet quinoneimine dye with absorbance at $505 \mathrm{~nm}$.

\section{DPP IV inhibitory activities of peptic hydrolysates of yam dioscorin}

The procedure for peptic hydrolysates of yam dioscorin was following the previous reports (Hsu et al. 2002; Liu et al. 2006). The hydrolytic ratio (wt/wt) of yam dioscorin (g) to pepsin (g) was set at 5/1 in $0.1 \mathrm{M} \mathrm{KCl}$ buffer ( $\mathrm{pH} 2.0$ ) with stirring at $4^{\circ} \mathrm{C}$ for 3 days. After hydrolysis, $1.0 \mathrm{M}$ Tris- $\mathrm{HCl}$ buffer ( $\mathrm{pH} 8.3$ ) was added to $\mathrm{pH} 7.5$ to stop hydrolysis. The molecular cut-off centricon or centriprep device (YM-10, 10 kD; YM-3, 3 kD; Millipore Co., USA) was used to separate peptic hydrolysates of yam dioscorin into three portions as followings: higher than $10 \mathrm{kD}$ (peptide > $10 \mathrm{kDa})$, between 3 to $10 \mathrm{kD}(3 \mathrm{kD}<$ peptide $<10 \mathrm{kD})$, and less than $3 \mathrm{kDa}$ (peptide $<3 \mathrm{kD}$ ). The fractions of between 3 to $10 \mathrm{kD}(3 \mathrm{kD}<$ peptide $<10 \mathrm{kD}$ ) and less than $3 \mathrm{kDa}$ (peptide $<3 \mathrm{kD}$ ) were further analyzed by reverse-phase C18 Spherical HPLC column $(10 \mathrm{~mm} \times 250 \mathrm{~mm})$. The mobile phase was mixed in stepwise gradients with solvent $\mathrm{A}$ (deionized water containing $0.1 \%$ trifluoroacetic acid) and solvent B (100\% acetonitrile containing $0.1 \%$ trifluoroacetic acid) as followings, 0 to $5 \mathrm{~min}, 100 \%$ to $79 \%$ solvent $\mathrm{A}$ and 0 to $21 \%$ solvent $\mathrm{B} ; 21 \mathrm{~min}, 75 \%$ solvent $\mathrm{A}$ and $25 \%$ solvent B; $22 \mathrm{~min}$ to $27 \mathrm{~min}, 60 \%$ solvent A and $40 \%$ solvent B; $40 \mathrm{~min}, 0 \%$ solvent A and $100 \%$ solvent B. Flow rate was $3 \mathrm{ml} / \mathrm{min}$. The detector was set at $220 \mathrm{~nm}$. The latter two fractions were lyophilized for DPP IV inhibitory assays. The DPP IV inhibitory activity was assayed according the previous report (Lacroix and Li-Chan 2013) with modifications. The DPP IV enzyme powder ( $\geq 10$ units/mg protein) was re-dissolved in $1 \mathrm{ml}$ of $100 \mathrm{mM}$ Tris buffer ( $\mathrm{pH}$ 8.0) as a stock enzyme solution and a 50-fold dilution before uses as a working enzyme solution. The substrate, Gly-Pro $p$-nitroanilide, was prepared as $4 \mathrm{mM}$ stock solutions. The sitagliptin phosphate, the DPP IV inhibitor (Drucker et al. 2007) as the positive control, was prepared as $1 \mu \mathrm{M}$ stock solutions. Each $50 \mu \mathrm{l}$ of working DPP IV enzyme solution and peptic dioscorin fractions was mixed at $37^{\circ} \mathrm{C}$ for $10 \mathrm{~min}$, then $50 \mu \mathrm{l}$ of substrate was added and adjusted to $200 \mu$ by $100 \mathrm{mM}$ Tris buffer ( $\mathrm{pH} 8.0$ ). The sitagliptin phosphate was used instead of tested dioscorin fraction for the control. The $100 \mathrm{mM}$ Tris buffer ( $\mathrm{pH}$ 8.0) was used instead of tested dioscorin fraction for the blank. The absorbance at $405 \mathrm{~nm}$ was measured at $60 \mathrm{~min}$ by using an ELISA reader (TECAN Sunrise microplate reader; Männedorf, Switzerland). The DPP IV inhibition (\%) was calculated as (A405 blank $_{\text {- }} 4405_{\text {sample or control }} /$ A $\left.405_{\text {blank }}\right) \times 100 \%$.

\section{Statistical analyses}

Data were expressed as mean \pm SEM in the rat weight changes and impaired glucose tolerances by OGTT methods, others were expressed as mean \pm SD. Multiple group comparisons under the same treated time were performed using one-way analysis of variance (ANOVA) followed by the post hoc Tukey's test, and values that have not been indicated with the same alphabet were significantly different $(P<0.05)$. Statistical analysis was performed using the GraphPad Prism 5.0 software (San Diego, CA, USA).

\section{Results}

Effects of dioscorin interventions on body weights of HF diet-induced obese rats

At the day 36, the average weight of rats in the group of normal diet, HF diet, and (HF diet + dio50) was $389.65 \pm$ $22.79(\mathrm{~g}), 462.25 \pm 11.06(\mathrm{~g})$, and $459.32 \pm 38.94(\mathrm{~g})$, respectively. At the day 68 , the average weight of rats in the group of normal diet, HF diet, and (HF diet + dio50) was $427.17 \pm 18.20$ (g), $514.90 \pm 13.44$ (g), and $509.76 \pm 28.54$ (g), respectively. Rats fed with the standard chow (the normal diet) showed lighter average body weights and significant difference $(P<0.05)$ compared to those fed with HF diets without or with dioscorin interventions during 70day experiments (Figure 1A). While, the average weight of rats in two groups of $\mathrm{HF}$-induced obese rats, namely $\mathrm{HF}$ diet group or with yam dioscorin interventions (HF diet + dio50) group showed no significant differences $(P>0.05)$ at the beginning (day 36) and the ends (day 68) of experiments (Figure 1A). It meant that yam dioscorin interventions at $50 \mathrm{mg} / \mathrm{kg}$ for 5 weeks showed no weight reduction activity against obese-induced rats at the present protocol designs. Figure 1B showed the feed 

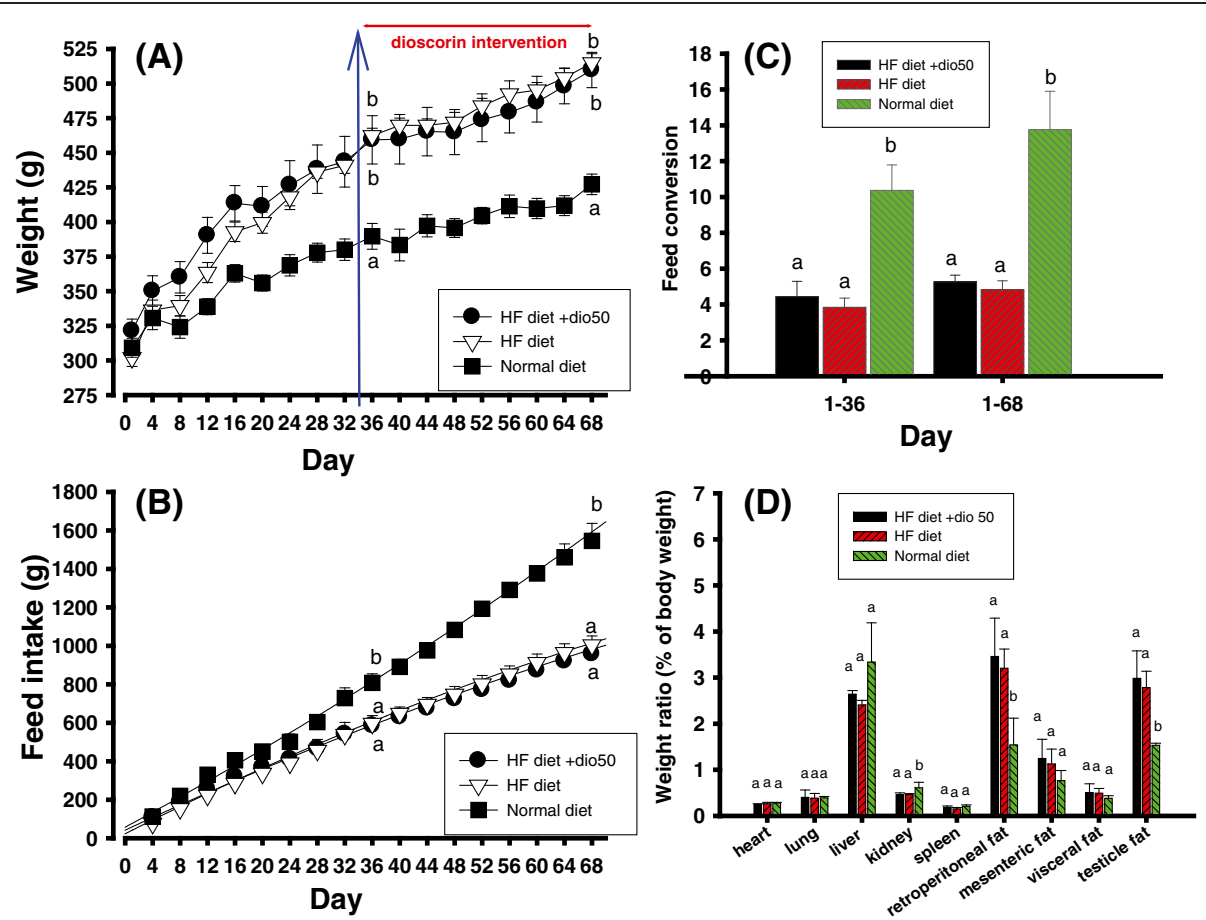

Figure 1 Effects of dioscorin interventions $(50 \mathrm{mg} / \mathrm{kg}$ ) on (A) body weights, (B) feed intakes, (C) feed conversion (feed intakes/weight gains), and(D) weights of organ and fat tissues of high fat-diet induced obese rats. Arrow indicates the dioscorin intervention from day 36 to day 70. Data were expressed as mean \pm SEM in the rat weight changes and others were expressed as mean \pm SD. Multiple group comparisons under the same treated time were performed using one-way analysis of variance followed by the post hoc Tukey's test, and values that have not been indicated with the same alphabet were significantly different $(P<0.05)$. HF, a high-fat diet; (HF diet + dio50), yam dioscorin $(50 \mathrm{mg} / \mathrm{kg}$, dio50) was intervened daily concurrent HF diet.

intakes during experiments. The feed intakes in three rat groups were showed linearly increases, while, rats fed with the standard chow (the normal diet) showed higher feed intakes and significant difference $(P<0.05)$ compared to those fed with HF diets without or with dioscorin interventions during 70-day experiments (Figure 1B). Figure 1C showed the feed conversion rate of three rat groups during obesity-induced and the whole experimental stages which was calculated from feed intakes (data in the Figure 1B) divided by weight gained (data in the Figure 1A). Rats fed with the standard chow (the normal diet) showed higher feed conversion rate and significant difference $(P<0.05)$ compared to those fed with HF diets without or with dioscorin interventions during obesity-induced and the whole experimental stages (Figure 1C). It meant that more of standard chow (the normal diet) were needed compared to those of HF diet to gain the same weight. Figure 1D showed the organ weights of three rat groups. Generally, rats in the normal diet group showed significant difference $(P<0.05)$ and lower weights of adipose tissues (such as retroperitoneal fat and testicle fat) than those in the HF diet groups. Other organs except from kidney showed no significant difference among three groups $(P>0.05)$.
Effects of dioscorin interventions on blood pressures of $\mathrm{HF}$ diet-induced obese rats

Figure 2 showed the changes of SBP (Figure 2A) and DBP (Figure 2B) in three rat groups after obesityinduced stages (day 36 to day 70). From the results of Figure $2 \mathrm{~A}$, the rats in the normal diet group showed lower SBP and significant differences $(P<0.05)$ compared to those in the HF diet group at 6-, 7-, 8-, and 9week. While, dioscorin intervention group (HF diet + dio50) showed lower SBP and significant differences $(P<$ 0.05) compared to those in the HF diet group at 7-, 8-, and 9-week (corresponding to dioscorin intervention for 2 weeks, 3 weeks, and 4 weeks, respectively) and comparable to those in the normal diet group. From the results of Figure $2 \mathrm{~B}$, the rats in the normal diet group showed lower DBP and significant differences $(P<0.05)$ compared to those in the HF diet group at 6-, 7-, 8-, and 9-week. Dioscorin intervention group (HF diet + dio50) showed lowered SBP, however, did not exhibit significant differences $(P>0.05)$ compared to those in the HF diet group at 7-, 8-, and 9-week. These results showed that the dioscorin intervention could improve blood pressure in obese rats, especial for SBP. 


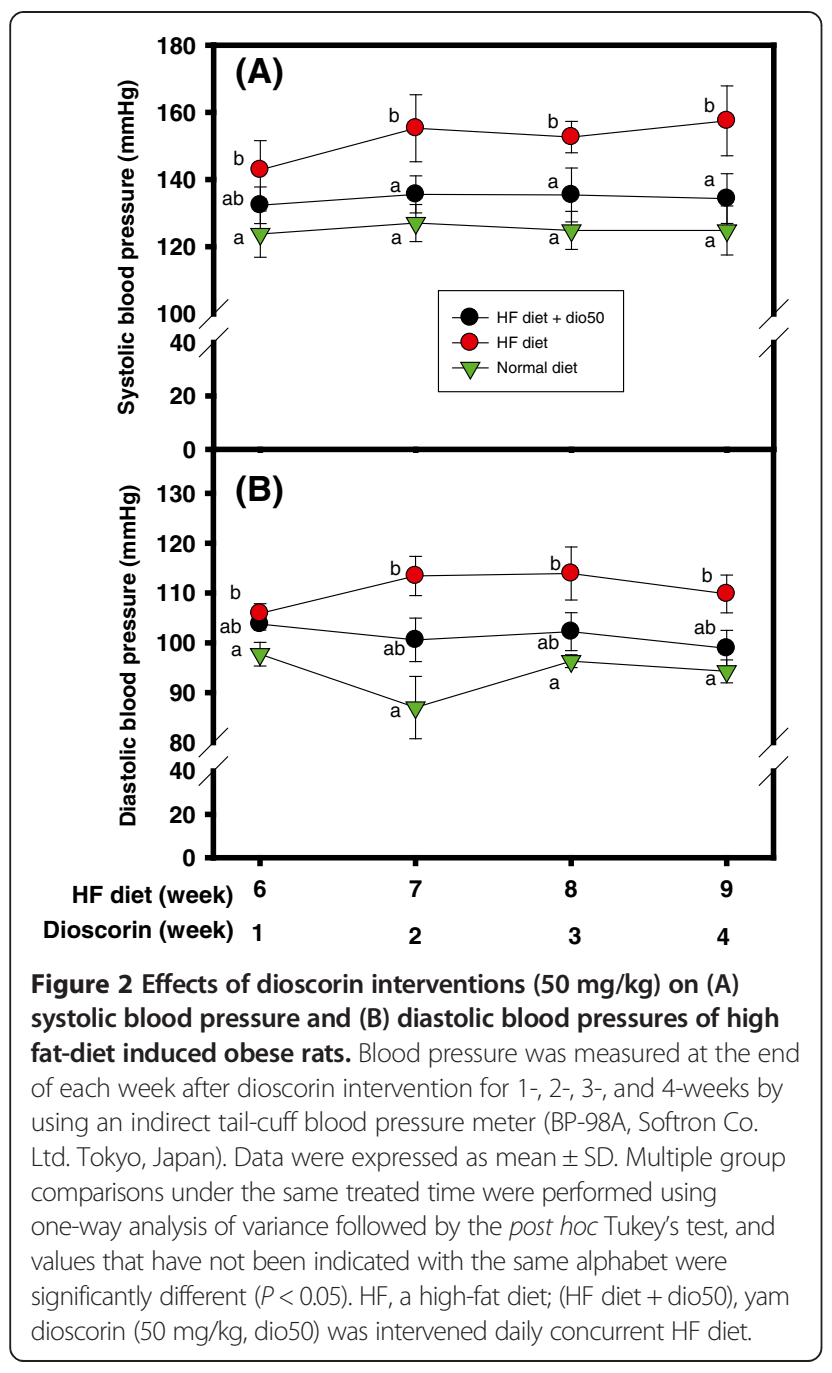

Effects of dioscorin interventions on impaired glucose tolerances of $\mathrm{HF}$ diet-induced obese rats

After fasting overnight, the impaired glucose tolerance of rats in three groups were measured by OGTT (Figure 3). Plasma glucose concentrations $(\mathrm{mg} / \mathrm{dL})$ of the normal diet group in the $0,5,30,60,90$, and 120 min were $81.19 \pm$ 6.09, $96.22 \pm 18.67,117.13 \pm 15.22,103.90 \pm 5.22,92.14 \pm$ 7.57 , and $87.24 \pm 3.77$, respectively; plasma glucose concentrations $(\mathrm{mg} / \mathrm{dL})$ of HF diet group were $95.40 \pm 5.66$, $101.67 \pm 4.07,113.39 \pm 5.04,111.75 \pm 5.51,105.48 \pm 7.02$, and $108.05 \pm 8.34$, respectively; plasma glucose concentrations $(\mathrm{mg} / \mathrm{dL})$ of $(\mathrm{HF}$ diet + dio50) group were $78.31 \pm$ $6.66,83.66 \pm 3.06,99.50 \pm 8.42,89.92 \pm 6.08,86.59 \pm 7.52$, and $81.14 \pm 7.21$, respectively. At the beginning, rats in the normal diet group and (HF diet + dio50) group showed lower plasma glucose concentrations and significant differences $(P<0.05)$ compared to those in the HF diet group. Later, rats in the (HF diet + dio50) group kept the lowest plasma glucose concentrations and significant differences $(P<0.05)$ among three rat groups at each 5-min, 30-min,

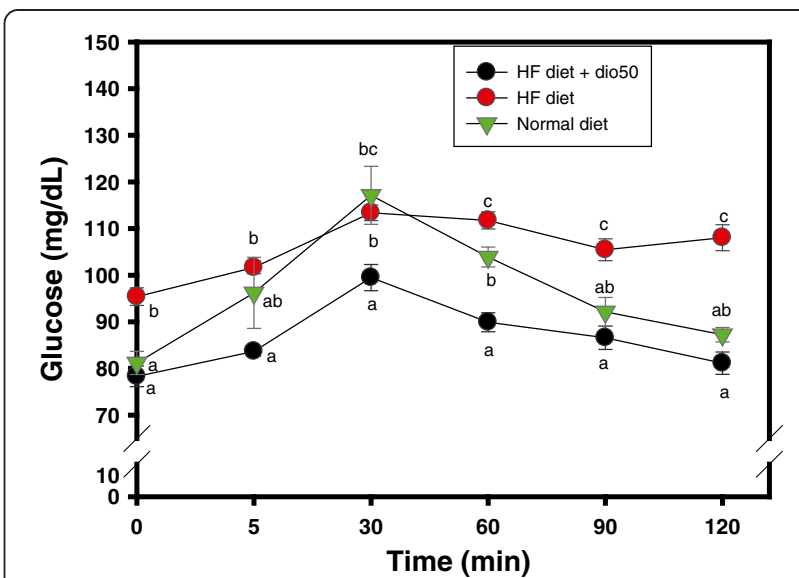

Figure 3 Effects of dioscorin interventions $(50 \mathrm{mg} / \mathrm{kg}$ ) on impaired glucose intolerances of high fat-diet induced obese rats by oral glucose tolerance tests. Data were expressed as mean \pm SEM. Multiple group comparisons under the same treated time were performed using one-way analysis of variance followed by the post hoc Tukey's test, and values that have not been indicated with the same alphabet were significantly different $(P<0.05)$. HF, a high-fat diet; (HF diet + dio50), yam dioscorin (50 mg/kg, dio50) was intervened daily concurrent HF diet.

60-min, 90-min, and 120-min time intervals and comparable to rats in the normal diet group at 90-min and 120min time intervals. The plasma glucose concentrations of rats in the normal diet groups and (HF diet + dio50) group were then back to the baseline at $120 \mathrm{~min}$, however, the plasma glucose concentrations of rats in the HF diet group were still kept at higher levels $(108.05 \pm 8.34 \mathrm{mg} / \mathrm{dL})$. From the OGTT data, it meant that the dioscorin intervention could improve impaired glucose tolerances of HF dietinduced obese rats.

\section{DPP IV inhibitory activities of peptic hydrolysates of yam dioscorin}

The reverse phase HPLC chromatograms of peptic hydrolysates of yam dioscorin with molecular mass between 3 $\mathrm{kD}$ and $10 \mathrm{kD}(3 \mathrm{kD}<$ peptide $<10 \mathrm{kD}$, Figure $4 \mathrm{~A})$ and less than $3 \mathrm{kD}$ (peptide $<3 \mathrm{kD}$, Figure $4 \mathrm{~B}$ ) were shown at Figure 4. These two hydrolytic fractions were used to analyze the DPP IV inhibitory activities compared to the positive control of sitagliptin phosphate (Figure 4C). The sitagliptin phosphate showed dose-dependent inhibitions against DPP IV. Under $5 \mathrm{mg} / \mathrm{ml}$ doses, the peptide fractions of $3 \mathrm{kD}<$ peptide $<10 \mathrm{kD}$ and peptide $<3 \mathrm{kD}$, respectively, showed $80.82 \pm 2.68$ (\%) and $54.42 \pm 3.51$ (\%) DPP IV inhibitory activities which might be equivalent to sitagliptin phosphate of $250.86 \mathrm{nM}$ and $61.79 \mathrm{nM}$, respectively.

\section{Discussion}

The present animal experiments showed that the dioscorin interventions at dose of $50 \mathrm{mg} / \mathrm{kg}$ daily for five 


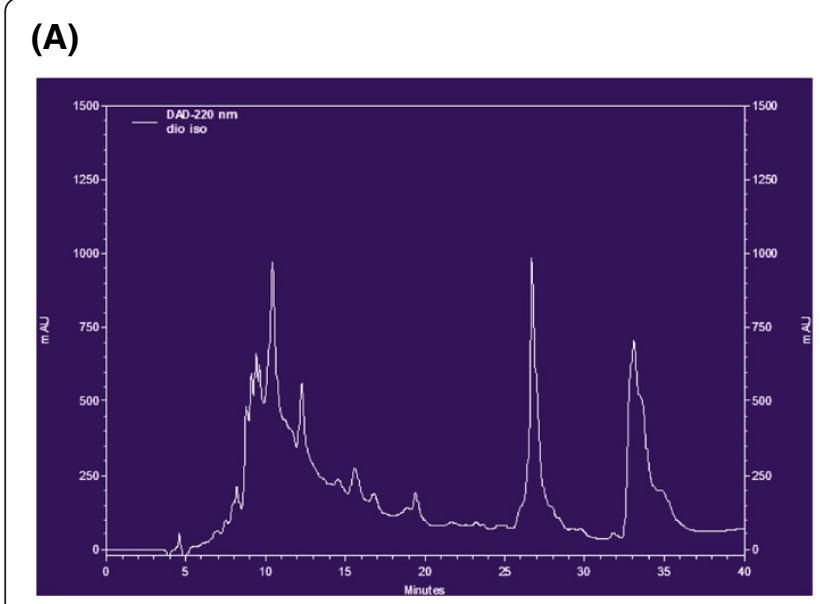

(B)
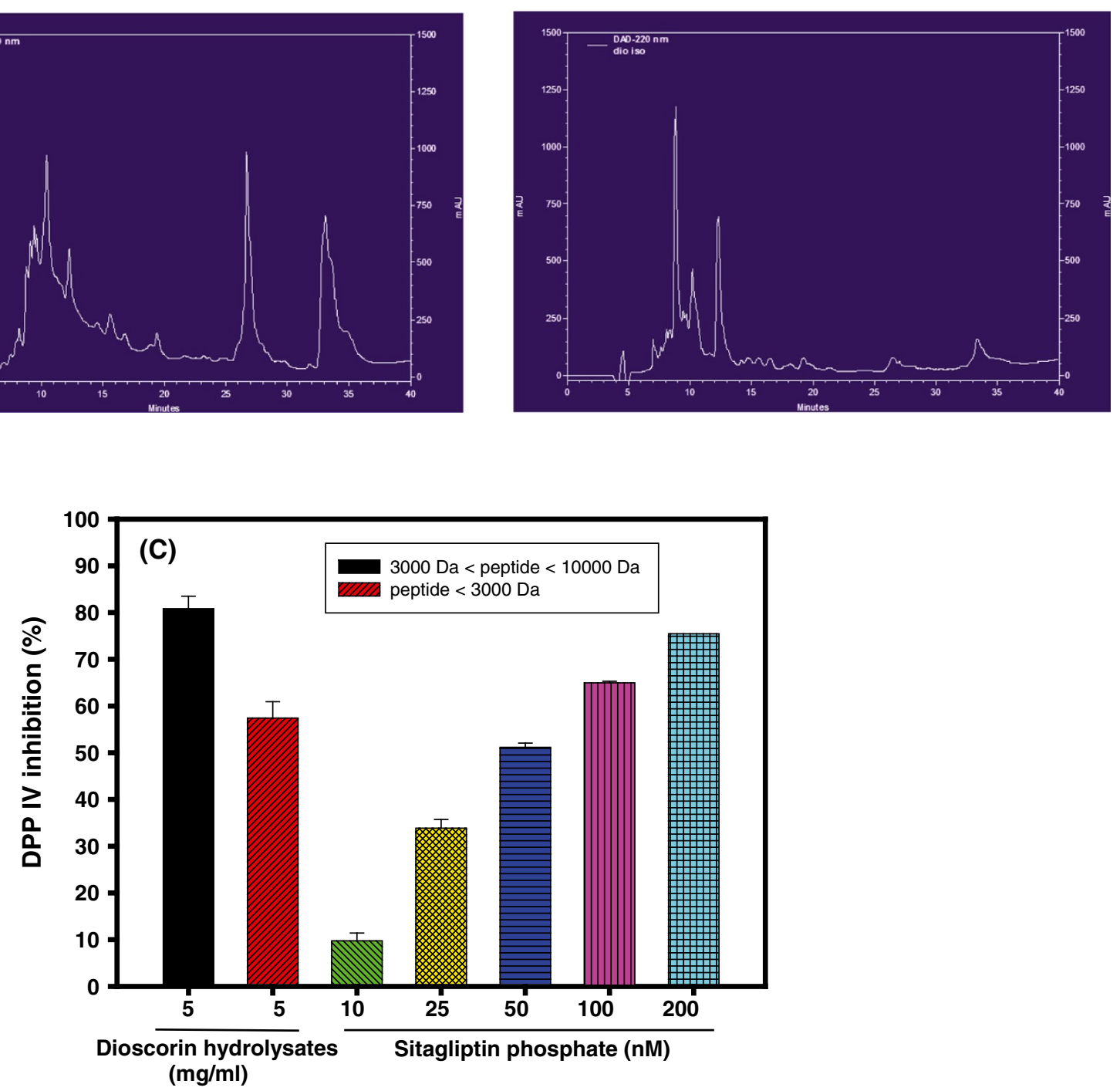

Figure 4 DPP IV inhibitory activities of peptic hydrolysates of yam dioscorin. (A) HPLC chromatograms of yam dioscorin peptic

hydrolysates with molecular mass between $3 \mathrm{kD}$ and $10 \mathrm{kD}$, (B) HPLC chromatograms of yam dioscorin peptic hydrolysates with molecular mass less than $3 \mathrm{kD}$, and (C) DPP IV inhibitory activities of two fractions $(5 \mathrm{mg} / \mathrm{ml}$ ) of dioscorin peptic hydrolysates from molecular cut-off membrane devices, and sitagliptin phosphate was acted as positive controls.

weeks could improve SBP and impaired glucose tolerances, but had no effects on reductions of body weight and fat tissues, of 10-week HF diet-induced obese rats which the improved metabolic risks were involved in MS criteria. The dioscorin and its peptic hydrolysates at doses of $40 \mathrm{mg} / \mathrm{kg}$ were showed to have antihypertensive activities against spontaneously hypertensive rats (SHR) (Lin et al. 2006); the dioscorin at doses of $20 \mathrm{mg} / \mathrm{kg}$ or $80 \mathrm{mg} / \mathrm{kg}$ showed to lower oxidative stress of BALB/c mice induced by subcutaneous galactose injections (Han et al. 2014b). The obesity may play the central role in MS which the renin-angiotensin system in dysfunctional adipocytes will initiate inflammation and dyslipidemia, increase blood pressure and decrease insulin sensitivity accompanied with abnormal blood glucose (Frigolet et al. 2013). Therefore, anti-obesity or prevention against obesity may reduce directly the risks of MS. There were several reports concerning anti-obesity activity from natural resources in rodent models induced by HF diets, such as $\alpha$-lipoic acid (Kim et al. 2004), cryptotanshinone from Salvia militorrhiza (Kim et al. 2007), rutin and ocoumaric acid (Hsu et al. 2009), honokiol and magnolol (Kim et al. 2013), pectin pentaoligosaccharide ( $\mathrm{Li}$ et al. 2013), high taurine and glycine contents of scallop protein (Tastesen et al. 2014). The above-mentioned models for HF diet-induced obese studies were generally applied 
either by HF diet pretreatment for a period of time and then tested sample interventions or co-treatment of HFdiet and tested samples in the same time. The vasorelaxing peptides of Arg-Phe and Ile-His-Arg-Phe derived from rice glutelin protein showed to lower food intakes in rodent models (Kagebayashi et al. 2012; Kontani et al. 2014) which maybe have anti-obesity activity. At present, it is not sure that less amounts of dioscorin used with the similar MS preventive activities, or higher amounts of dioscorin used or co-treatments of HF-diet and dioscorin used with anti-obesity activities. Reagan-Shaw et al. (2007) suggested to use body surface area normalization for dose translation from animal to human studies. It was calculated that the human equivalent dose was $8.11 \mathrm{mg} / \mathrm{kg}$ of human body weight from dioscorin intervention of $50 \mathrm{mg} / \mathrm{kg}$ of rat body weight in the present experiment. An adult of $60 \mathrm{~kg}$ weigh might have to consume about $490 \mathrm{mg}$ dioscorin/day to achieve benefits of improving MS and need further investigations.

The yam dioscorin and its peptic hydrolysates or synthesized peptides derived from dioscorin had been reported to lower blood pressures using SHR as animal models (Lin et al. 2006; Liu et al. 2009a,b; Lin et al. 2014). From the present results of Figure 2, dioscorin intervention at least for two weeks showed to lower SBP of HF diet-induced obese rats and comparable to the normal diet fed ones. The dysfunctional adipocytes in obesity will increase circulating renin-angiotensin systems, and the generated angiotensin II from angiotensin I by angiotensin converting enzyme (ACE) hydrolysis resulted in the higher blood pressures (Frigolet et al. 2013). It was reported that obesity may elevate systemic oxidative stress from overloaded nutrients of HF diets and advanced glycation endproduct generations (Kahn et al. 2006). Glycation is the non-enzymatic modification of proteins through the reduction of sugars and their metabolized intermediates, such as glyoxal or methylglyoxal, and leads to the irreversible formation of advanced glycation end products (Kikuchi et al. 2003). The hypertensive rat might increase oxidative stress and methylglyoxal amounts in vascular smooth muscle cells (Wu and Juurlink 2002). The peptic hydrolysates of dioscorin showed ACE inhibitory activities (Hsu et al. 2002) and the synthesized peptides derived from pepsin hydrolysates in silico vasorelaxing activities (Lin et al. 2014). The synthesized peptides derived from pepsin hydrolysates in silico exhibited antioxidant and antiglycation activities in vitro and in vivo (Han et al. 2013; Han et al. 2014a,c). It was proposed that the dioscorin intervention showed to lower SBP of HF diet-induced obese rats might be from ACE inhibitory and vasorelaxing activities, and in part from antioxidant and/or antiglycation activities of active peptides after dioscorin ingestions and need further investigations.
From the results of Figure 3, it was found that the impaired glucose tolerances in HF diet-induced obese rats were improved after dioscorin interventions by OGTT methods. At the beginning and the end of OGTT test, the obese rats exhibited significantly higher glucose levels compared to rats in normal diet group and (HF + dio50) group. From the results of Figure 4, it was found that yam dioscorin peptic hydrolysates with molecular mass $3 \mathrm{kD}<$ peptide $<10 \mathrm{kD}$ and less than $3 \mathrm{kD}$ at doses of $5 \mathrm{mg} / \mathrm{ml}$ showed DPP IV inhibitory activities in vitro which might be equivalent to effects of $250.86 \mathrm{nM}$ and $61.79 \mathrm{nM}$ of sitagliptin phosphate, respectively. Moreover, the undigested dioscorin was also used to evaluate DPP IV inhibitory activity, under $5 \mathrm{mg} / \mathrm{ml}$ concentration, which showed $40.7 \%$ DPP IV inhibition (data not show). The native dioscorin showed less anti-DPP IV activity compared to the $3 \mathrm{kD}<$ peptide $<10 \mathrm{kD}$ and less than $3 \mathrm{kD}$ of dioscorin peptic hydrolysates. The results of DPP IV activity of the native and digested dioscorin is in agreement with the general observation that shortchain biologically active peptides can be released and absorbed in the small intestine after oral administration (Phelan et al. 2009) which may correlate with the improved OGTT. The sitagliptin phosphate, DPP IV inhibitor approved by US FDA in 2006, can prolong GLP-1 biological activities to stimulate glucose-dependent insulin secretions and for type $2 \mathrm{DM}$ treatment in vivo (Idris and Donnelly 2007; Drucker et al. 2007). The DPP IV inhibitor (valine-pyrrolidide) showed the improved glucose tolerance and insulin secretion in HF diet-fed C57BL/6 J mice (Ahrén et al. 2000). The mice fed a HF diet (58\% fat) together with DPP IV inhibitor (NVP DPP728) in the drinking water for 8 weeks showed the improved glucose tolerance and increased circulating levels of insulin and GLP-1 compared to HF diet only (Reimer et al. 2002). It was suggested that the improved glucose tolerance in HF diet-induced obese rats after dioscorin interventions might be in part from DPP IV inhibitory activities of active peptides from dioscorin after being ingested and need further investigations.

\section{Conclusions}

In conclusion, yam dioscorin interventions exhibit the improved MS activities in obese rats and peptic hydrolysates of yam dioscorin in vitro exhibit DPP IV inhibitory activities which the related mechanisms may need further investigations.

\section{Competing interests}

The authors declare that they have no competing interests.

\section{Authors' contributions}

SLS, SYL, and WCH participated the discussion and concepts of experimental designs, MS writing and revision; YSL performed experiments. All authors read and approved the final manuscript. 


\section{Acknowledgements}

The authors would like to express thanks to Yuan's General Hospital, Kaohsiung, Taiwan (103YGH-TMU-02-3) and Ministry of Science and Technology, Republic of China (NSC 102-2313-B-038 -004 -MY3) for financial supports.

\section{Author details}

'Yuan's General Hospital, Department of Breast Surgery and Cancer Center, Kaohsiung, Taiwan. ${ }^{2}$ Graduate Institute of Pharmacognosy, Taipei Medical University, Taipei, Taiwan. ${ }^{3}$ Department of Primary Care Medicine, Taipei Medical University Hospital, Taipei, Taiwan. ${ }^{4}$ Department of General Medicine, School of Medicine, Taipei Medical University, Taipei, Taiwan. ${ }^{5}$ Traditional Herbal Medicine Research Center, Taipei Medical University Hospital, Taipei, Taiwan. ${ }^{6}$ Program for the Clinical Drug Discovery from Botanical Herbs, Taipei Medical University, Taipei, Taiwan.

\section{Received: 27 October 2014 Accepted: 7 February 2015} Published online: 25 February 2015

\section{References}

Agulia MB, Mandarim-de-Lacerda CA (2003) Heart and blood pressure adaptations in Wistar rats fed with different high-fat diets for 18 months. Nutrition 19:347-352

Ahrén B, Holst JJ, Mårtensson H, Balkan B (2000) Improved glucose tolerance and insulin secretion by inhibition of dipeptidyl peptidase IV in mice. Eur J Pharmacol 404:239-245

Alberti KGMM, Eckel RH, Grundy SM, Zimmet PZ, Cleeman Jl, Donato KA, Fruchart J-C, James WPT, Loria CM, Smith SC Jr (2009) Harmonizing the metabolic syndrome: a joint interim statement of the international diabetes federation task force on epidemiology and prevention; national heart, lung, and blood institute; american heart association; world heart federation; international atherosclerosis society; and international association for the study of obesity. Circulation 120:1640-1645

Andrikopoulos A, Blair AR, Deluca N, Fam BC, Proietto J (2008) Evaluating the glucose tolerance test in mice. Am J Physiol Endocrinol Metab 295:E1323-E1332

Daniels J (2006) Obesity: America's epidemic. Am J Nurs 106:40-49

Day C (2007) Metabolic syndrome, or what you will: definitions and epidemiology. Diabetes Vasc Dis Res 4:32-38

Drucker DJ (2006) The biology of incretin hormones. Cell Metab 3:153-165

Drucker D, Easley C, Kirkpatrick P (2007) Sitagliptin. Nat Rev Drug Discover 6:109-110

Frigolet ME, Nimbe Torres N, Armando R, Tovar AR (2013) The renin-angiotensin system in dipose tissue and its metabolic consequences during obesity. J Nutr Biochem 24:2003-2015

Han CH, Liu JC, Fang SU, Hou WC (2013) Antioxidant activities of the synthesized thiol-contained peptides derived from computer-aided pepsin hydrolysis of yam tuber storage protein, dioscorin. Food Chem 138:923-930

Han CH, Lin YS, Lin SY, Hou WC (2014a) Antioxidant and antiglycation activities of the synthesised dipeptide, Asn-Trp, derived from computer-aided simulation of yam dioscorin hydrolysis and its analogue, Gln-Trp. Food Chem 147:195-202

Han CH, Lin YF, Lin YS, Lee TL, Huang WJ, Lin SY, Hou WC (2014b) Effects of yam tuber protein, dioscorin, on attenuating oxidative status and learning dysfunction in D-galactose-induced BALB/c mice. Food Chem Toxicol 65:356-363

Han CH, Lin YS, Lee TL, Liang HJ, Hou WC (2014c) Asn-Trp dipeptides improve the oxidative stress and learning dysfunctions in $D^{-g a l a c t o s e-i n d u c e d ~}$ BALB/C mice. Food Funct 5:2228-2236

Hatanaka T, Inoue Y, Arima J, Kumagai Y, Usuki H, Kawakami K, Kimura M, Mukaihara T (2012) Production of dipeptidyl peptidase IV inhibitory peptides from defatted rice bran. Food Chem 134:797-802

Hou WC, Chen HJ, Lin YH (2000) Dioscorins from different Dioscorea species all exhibit both carbonic anhydrase and trypsin inhibitor activities. Bot Bull Acad Sin 41:191-196

Hou WC, Lee MH, Chen HJ, Liang WL, Han CH, Liu YW, Lin YH (2001) Antioxidant activities of dioscorin, the storage protein of yam (Dioscorea batatas Decne) tuber. J Agric Food Chem 49:4956-4960

Hsu FL, Lin YH, Lee MH, Lin CL, Hou WC (2002) Both dioscorin, the tuber storage protein of yam (Dioscorea alata cv. Tainong No. 1), and its peptic hydrolysates exhibited angiotensin converting enzyme inhibitory activities. J Agric Food Chem 50:6109-6113

Hsu CL, Wu CH, Huang SL, Yen GC (2009) Phenolic compounds rutin and o-coumaric acid ameliorate obesity induced by high-fat diet in rats. J Agric Food Chem 57:425-431
Idris I, Donnelly R (2007) Dipeptidyl peptidase-IV inhibitors: a major new class of oral antidiabetic drug. Diabetes Obes Metab 9:153-165

Ito M, Kondo Y, Nakatani A, Hayashi K, Naruse A (2001) Characterization of low dose streptozotocin-induced progressive diabetes in mice. Envir Texicol Pharmacol 9:71-78

Kagebayashi T, Kontani N, Yamada Y, Mizushige T, Arai T, Kino K, Ohinata K (2012) Novel CCK-dependent vasorelaxing dipeptide, Arg-Phe, decreases blood pressure and food intake in rodents. Mol Nutr Food Res 56:1456-1463

Kahn SE, Hull RL, Utzschneider KM (2006) Mechanisms linking obesity to insulin resistance and type 2 diabetes. Nature 444:840-846

Kikuchi S, Shinpo K, Takeuchi M, Yamagishi S, Makita Z, Sasaki N, Tashiro K (2003) Glycation-a sweet tempter for neuronal death. Brain Res Rev 41:306-323

Kim MS, Park JY, Namkoong C, Jang PG, Ryu JW, Song HS, Yun JY, Namgoong IS, Ha J, Park IS, Lee IK, Viollet B, Youn JH, Lee HK, Lee KU (2004) Anti-obesity effects of a-lipoic acid mediated by suppression of hypothalamic AMP-activated protein kinase. Nat Med 10:727-733

Kim EJ, Jung SN, Son KH, Kim SR, Ha TY, Park MG, Jo IG, Park JG, Choe W, Kim SS, $\mathrm{Ha} J$ (2007) Antidiabetes and antiobesity effect of cryptotanshinone via activation of AMP-activated protein kinase. Mol Pharmacol 72:62-72

Kim YJ, Choi MS, Cha BY, Woo JT, Park YB, Kim SR, Jung UJ (2013) Long-term supplementation of honokiol and magnolol ameliorates body fat accumulation, insulin resistance, and adipose inflammation in high-fat fed mice. Mol Nut food Res 57:1988-1998

Kobayasi R, Akamine EH, Davel AP, Rodrigues MAM, Carvalho CRO, Rossoni LV (2010) Oxidative stress and inflammatory mediators contribute to endothelial dysfunction in high-fat diet-induced obesity in mice. J Hypertens 28:2111-2119

Kontani N, Omae R, Kagebayashi T, Kaneko K, Yamada Y, Mizushige T, Kanamoto R, Ohinata K (2014) Characterization of Ile-His-Arg-Phe, a novel rice-derived vasorelaxing peptide with hypotensive and anorexigenic activities. Mol Nutr Food Res 58:359-364

Lacroix IME, Li-Chan ECY (2012) Dipeptidyl peptidase-IV inhibitory activity of dairy protein hydrolysates. Int Dairy J 25:97-102

Lacroix IME, Li-Chan ECY (2013) Inhibition of dipeptidyl peptidase (DPP)-IV and a-glucosidase activities by pepsin-treated whey proteins. J Agric Food Chem 61:7500-7506

Li T, Zhu R, Dong Y, Liu Y, Li S, Chen G (2013) Effects of pectin pentaoligosaccharide from hawthorn (Crataegus pinnatifida Bunge. var. Major) on the activity and mRNA levels of enzymes involved in fatty acid oxidation in the liver of mice fed a high-fat diet. J Agric Food Chem 61:7599-7605

Lin CL, Lin SY, Lin YH, Hou WC (2006) Effects of tuber storage protein of yam (Dioscorea alata cv. Tainong No. 1) and its peptic hydrolyzates on spontaneously hypertensive rats. J Sci Food Agric 86:1489-1494

Lin YS, Lu YL, Wang GJ, Liang HJ, Hou WC (2014) Vasorelaxing and antihypertensive activities of synthesized peptides derived from computer-aided simulation of pepsin hydrolysis of yam dioscorin. Bot Stud 55:49, doi:10.1186/s40529-014-0049-3

Liu YH, Liang HJ, Cheng HC, Liu YW, Hou WC (2006) Comparisons of in vitro antioxidant activities of storage proteins in tuber of two Dioscorea species. Bot Stud 47:231-237

Liu DZ, Liang HJ, Han CH, Lin SY, Chen CT, Fan M, Hou WC (2009a) Feeding trial of instant food containing lyophilised yam powder in hypertensive subjects. J Sci Food Agric 89:138-143

Liu YH, Lin YS, Liu DZ, Han CH, Chen CT, Fan M, Hou WC (2009b) Effects of different types of yam (Dioscorea alata) products on the blood pressure of spontaneously hypertensive rats. Biosci Biotechnol Biochem 73:1371-1376

Lu YL, Chia CY, Liu YW, Hou WC (2012) Biological activities and applications of dioscorins, the major tuber storage proteins of yam. J Tradit Complement Med 2:41-46

Mentlein R (2005) Therapeutic assessment of glucagon-like peptide-1 agonists compared with dipeptidyl peptidase IV inhibitors as potential antidiabetic drugs. Expert Opin Investig Drugs 14:57-64

Panchal SK, Brown L (2011) Rodent models for metabolic syndrome research. J Biomed Biotech 2011:351982, doi: 10.1155/2011/351982

Phelan M, Aherne A, FitzGerald RJ, O'Brien NM (2009) Casein-derived bioactive peptides: biological effects, industrial uses, safety aspects and regulatory status. Int Dairy J 19:43-654

Prentice AM (2006) The emerging epidemic of obesity in developing countries. Int J Epidemiol 35:93-99

Reagan-Shaw S, Nihal M, Ahmad N (2007) Dose translation from animal to human studies revisited. FASEB J 22:659-661

Reimer MK, Holst JJ, Ahrén B (2002) Long-term inhibition of dipeptidyl peptidase IV improves glucose tolerance and preserves islet function in mice. Eur J Endocrinol 146:717-727 
Rodgers RJ, Tschöp MH, Wilding JPH (2012) Anti-obesity drugs: past, present and future. Dis Model Mech 5:621-626

Smyth S, Heron A (2005) Diabetes and obesity: the twin epidemics. Nat Med 12:75-80

Tastesen HS, Keenan AH, Madsen L, Kristiansen K, Liaset B (2014) Scallop protein with endogenous high taurine and glycine content prevents high-fat, high-sucrose-induced obesity and improves plasma lipid profile in male C57BL/6 J mice. Amino Acids 46:1659-1671

Woods SC, Seeley RJ, Rushing PA, D'Alessio D, Tso P (2003) A controlled high-fat diet induces an obese syndrome in rats. J Nutr 133:1081-1087

Wu L, Juurlink BHJ (2002) Increased methylglyoxal and oxidative stress in hypertensive rat vascular smooth muscle cells. Hypertension 39:809-814

Zimmet P (1982) Type 2 (non-insulin-dependent) diabetes - an epidemiological overview. Diabetologia 22:399-411

Submit your manuscript to a SpringerOpen ${ }^{\circ}$ journal and benefit from:

- Convenient online submission

- Rigorous peer review

- Immediate publication on acceptance

- Open access: articles freely available online

- High visibility within the field

- Retaining the copyright to your article

Submit your next manuscript at $\gg$ springeropen.com 